\title{
Savings and Economic Growth in Botswana: An Analysis Using Bounds Testing Approach to Cointegration
}

\author{
*Kafayat Amusa, Moyo Busani \\ University of South Africa (UNISA), South Africa \\ *amusako@unisa.ac.za
}

\begin{abstract}
Economic growth boosted by high domestic savings has been advocated for by numerous economists throughout the years. For a country like Botswana where the savings- GDP ratio is relatively high, it becomes important to determine whether savings is indeed important for the economy. This paper reexamines the savings-growth debate for the Botswana economy by applying the Bounds testing approach to cointegration analysis to establish the relationship between domestic savings and economic growth in Botswana. The results indicate that domestic savings is significantly positively related to growth in Botswana. The study recommends the need for development of financial instruments to encourage domestic savings.
\end{abstract}

Keywords: Savings; Economic Growth; Bounds; Cointegration; Botswana

\section{Introduction}

The Botswana economy has been growing at an average rate of 7.5\% since 1980 far higher than Sub Saharan Africa's 3\% growth rate (WDI, 2012). This sterling growth has been driven largely by its mining sector and is therefore subjected to shocks from the global economy and its trading partners. There is a concerted effort by government to diversify the economy and reduce its reliance on diamond exports. One way of promoting diversification is by increasing the inflow of investment both local and foreign into the non minerals sectors like manufacturing, services etc. The role played by domestic savings and hence investment becomes crucial in supporting the country's diversified growth process. Solow (1956) posits that by increasing savings and therefore by extension investment, faster growth is achievable. This hypothesis was further complemented by the suggestion that nations with low investment stock but high savings would experience a faster growth pace than those with high investment and low savings. Thus the effect of higher savings is to increase the availability of funds for investment. The more capital goods a nation has at its disposal, the more goods and services it can produce and the higher the level of economic growth. Thus the implication is that since most developing countries like Botswana are capital importers, domestic savings are therefore needed to acquire more foreign capital for investment purposes. The ideas put forward by Solow gained further ground when in their seminal work, McKinnon (1973) and Shaw (1973) advocated for financial liberalization based on their findings that increased investments through increased savings enabled economic growth. As a result of years of numerous studies that have built on the early works of Solow (1956) and McKinnon (1973) and Shaw (1973), the general consensus reached by extant literature ${ }^{1}$ is that domestic savings plays a crucial role in promoting strong and sustained economic growth if channeled towards profitable, sound and appropriate investments opportunities. Policymakers, including the World Bank, have long advocated policies that lead to higher savings in order to boost economic growth for developing countries. The question that arises however is whether high savings actually promote economic growth, especially in nascent economies like Botswana? Thus the true nature of the relationship between savings and growth is of critical importance for development policy.

There exists a rich literature that examine the savings and growth nexus in both single and multi country contexts for developed and developing countries and employing a variety of estimation techniques. As

\footnotetext{
${ }^{1}$ Studies include amongst others; Bacha (1990), DeGregorio (1992), Saltz (1999), Aghion et al. (2009), Romm (2003) Odhiambo (2009), Lean and Song (2009), Tang and Chua(2011).
} 
expected the results for the most part are varied based on the country under study, technique used and years considered. The two avenues followed in the relationship are whether higher savings induce higher growth and whether growth enhances savings. The view that savings is essential for growth is supported by the growth models of Harrod (1939), Domer (1946) and Solow (1956) and more recent empirical works of Lean and Song (2009), Sheggu (2009). The alternative view that growth enhances savings is supported by findings from Sinha and Sinha (1998) Saltz (1999) and Anoruo and Ahmad (2001). Despite the policy significance of determining and quantifying the importance of savings in the growth process, there is still a paucity of empirical research analyzing the relationship between savings and economic growth in specific African countries $^{2}$. This is because the relationship may differ depending on the country under study and also because of mixed results from empirical studies. The aim of this study is to extend this debate to a country like Botswana and ascertain the nature of the relationship between savings and growth and thus suggest appropriate growth policies. In an attempt to address this issue, we draw on recent savings- growth modelling literature and examine the savings and growth relationship in Botswana using data from 19802008. This study utilizes an ARDL bounds testing approach to cointegration to determine both the long run and short run impacts of savings on economic growth.

\section{Overview of Savings and Economic Growth in Botswana}

Figure 1: Savings-GDP ratio comparisons between Regions and Botswana. 1980-2010

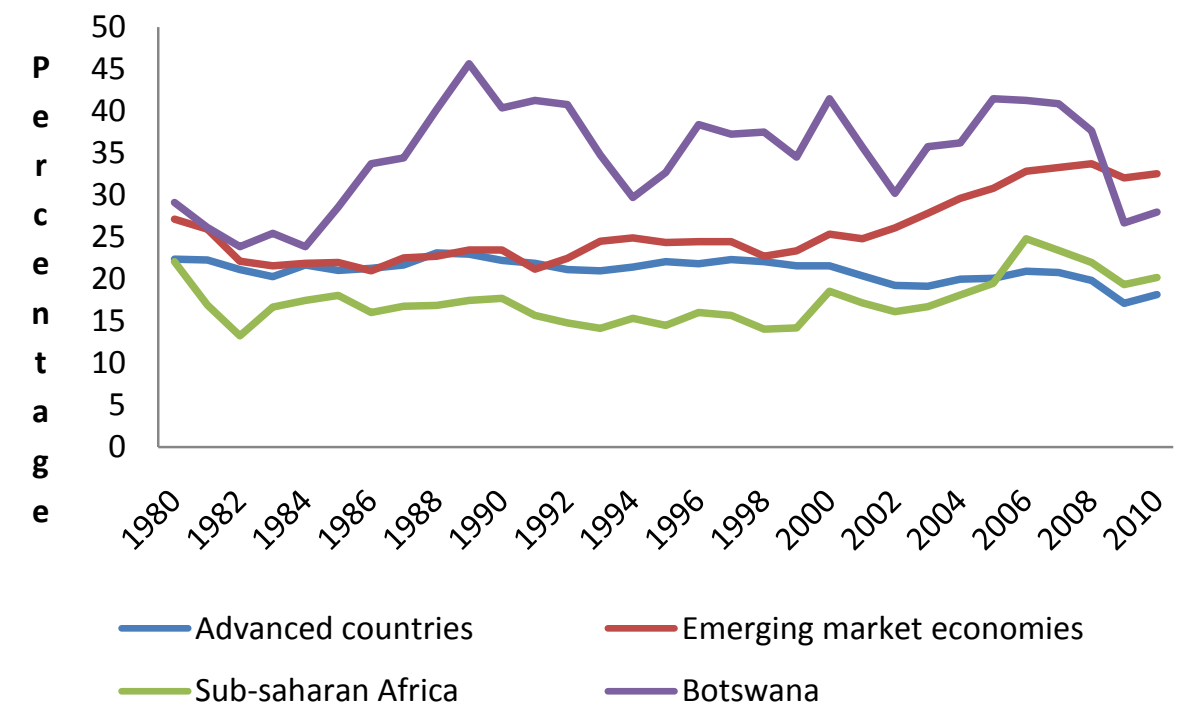

Source: World Economic Outlook online database (2012)

Development economics pushes the importance of savings for growth especially in developing countries where the sluggish growth has been attributed to low savings rate. A comparison of Botswana to other regions (advanced, emerging markets and Sub Saharan Africa regions) shows that the savings-GDP ratio for Botswana has historically been higher than that of countries in other regions. Comparing averages, in the 1980's savings GDP ratio averaged 22, 23, 17 and 31 percent respectively in Advanced, Emerging, Sub-Sahara countries and Botswana. Domestic savings in Botswana has been, and remains relatively high when observed in relation to gross domestic product (GDP) (see figure 2). In the 1980's the savings-GDP ratio increased year on year reaching a high of 50 percent of GDP in 1988. This was followed by periods of fluctuations, however the figure until 2005 remained as high as 43 percent of GDP. After 2006, a decline in the savings GDP ratio can

${ }^{2}$ Recent studies done on African countries include the ones by Odhiambo (2008 and 2009) on South Africa and Kenya; Romm (2003) on South Africa; Sheggu (2009) on Ethiopia as well as Annoruo and Ahmad (2001) on Ghana, Zambia, South Africa, Kenya, Ivory Coast and Congo. 
be observed, with the ratio falling to around 13 percent of GDP in 2008. There is an observed correlation between savings and gross domestic product.

\section{Figure 2: Gross domestic savings (\% of GDP) and growth rate of GDP. 1975-2008}

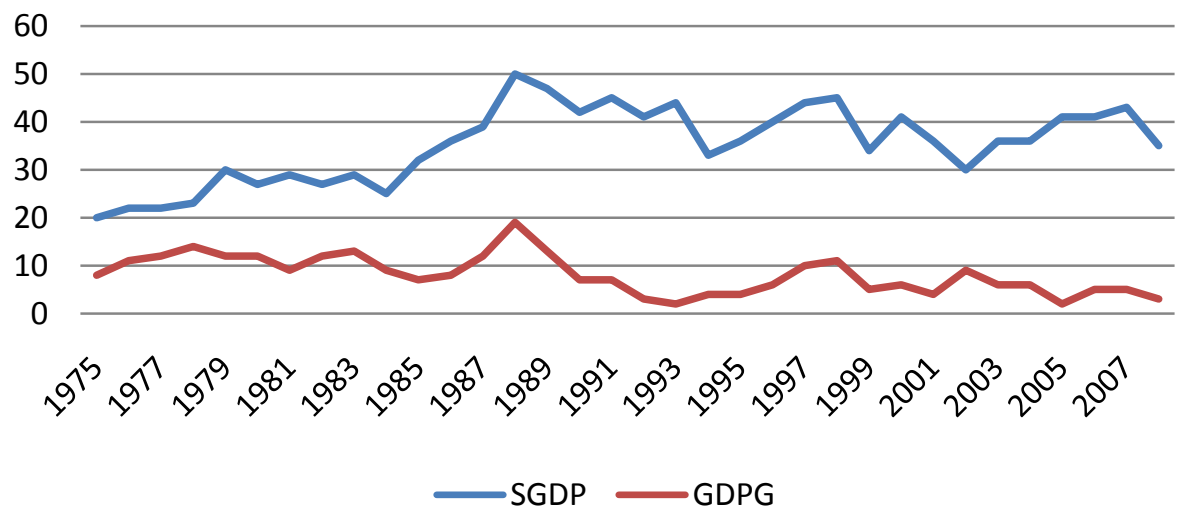

Source: World Development Indicators (Online).

The relatively high savings-GDP ratio Botswana experiences has been attributed to prudent fiscal spending by the government rather than due to high household savings as in the case of other countries. Additionally, monetary policy has been effective in ensuring that there is a constant and significant capital inflow from private sources (Bank of Botswana annual report, 2009).

\section{Literature Review}

The theories regarding the relationship between savings and economic growth are well known. Theoretically, by ensuring significant savings an economy will benefit in terms of growth. Harrod (1939), Domer (1946) and Solow (1956) growth models support the assertions that increased savings stimulate economic growth. The conventional idea has been that increased savings leads to increased growth; based on the belief that higher savings enables increased investment. Proponents to this school of thought include Giovannini, (1985); Lahiri, (1989), Bacha (1990), Carroll and Summers (1991); DeGregorio (1992), Jappelli and Pagano (1994); Fry, (1995); Edwards, (1996) Lean and Song (2009), Sheggu (2009); Aghion et al. (2009) who found a positive relationship between growth in savings and economic growth. The Alternative view that economic growth stimulates increased savings is drawn largely from the Keynes (1936) model and consumption theories, such as the permanent income and life cycle hypotheses. The latter theories imply that people choose their consumption (and hence also savings) levels depending on current and (expected) future income levels. These model predictions are supported by empirical findings by Sinha and Sinha, (1998); Saltz, (1999) as well as Anoruo and Ahmad (2001). Lean and Song (2009) examined the domestic savings and economic growth relationship for China from 1955-2004, employing cointegration and causality tests. China has enjoyed high levels of economic growth and savings for a number of decades and they found that indeed, there existed a long run relationship between economic growth and savings in China, taking into account the two savings rates they employed; household savings and enterprise savings. They found the existence of bilateral causality between domestic savings and economic growth in the short run and a unidirectional causality from domestic savings growth to economic growth in the long run. Tsikata (1998) highlights the importance of public savings for the South African economy, observing that declines in public savings results in an overall decline in aggregate savings. The finding implies that policies to address public savings are crucial. Romm (2003), using vector error correction model (VECM) approach examines the relationship between savings and growth in South Africa from 1946-1992. The results indicate that that there is an indirect effect of private savings growth through the effect of private savings on investment. The paper finds that savings enhanced growth and at the same time growth enhanced savings. 
Aghion et al. (2009) examine whether domestic savings matters for economic growth. Their model focuses on the idea that growth is a corollary from technological innovations and therefore in the case of poor countries who are constantly playing catch up to new technology, they require foreign investors to work together with domestic entrepreneurs who know the workings of the domestic economy. Therefore domestic savings is essential for innovation and growth. This however does not apply to developed or rich nations that already have the technological knowhow. They also argue that given the fact that investments can be financed by foreign savings, then domestic savings is not important for the growth process. Their study finds that domestic savings is more important for adopting new technologies in developing rather than developed nations. Savings and economic growth studies examining the direction of causality yield differing results. Mohan (2006) examined the relationship between savings and economic growth for high, middle and low income countries utilising annual data from 1960-2001. Contrary to the traditional view, the results indicated that causality ran from economic growth to savings. The findings also indicate that in countries with a forced savings policy like Singapore, causality runs from savings to economic growth. Similar results are observed by Sheggu (2009) who models the relationship between savings and economic growth in Ethiopia from 1960-2003 in a vector autoregressive model (VAR) model. Sheggu finds that faster growth rates in the gross domestic savings caused higher growth rates in real GDP in Ethiopia. Conversely, Saltz (1999) uses Granger causality in an error correction framework to investigate the causal relationship between savings and growth in the third world countries and finds that higher growth leads to faster growth in the savings rate. The result suggests that in addition to promoting higher savings, efforts promoting economic growth are also essential. Anoruo and Ahmad (2001) used a Vector Error Correction Model (VECM), on a sample of seven African countries, and found that there is a long-run relationship between economic growth and growth rate of savings. The results from the Granger-causality tests indicate that contrary to the conventional wisdom, economic growth prima facie causes growth rate of domestic savings for most of the countries under consideration. The authors found that in four out of seven countries, economic growth Granger caused the growth rate of domestic savings. However, they obtained a bi-directional causality in Cote d'Ivoire and South Africa. Only in the Congo, did the opposite result prevail: the growth rate of domestic savings Granger caused economic growth. Caroll and Weil (1994), using five-year averages of the economic growth rate and savings for OECD countries as well as a larger sample, found that economic growth rate Granger caused savings in the larger sample. On the other hand, when time dummies were not included, savings Granger caused growth in the OECD countries. However, Attanasio et al. (2000) criticized the robustness of Caroll and Weil's results, finding that using annual data rather than the five-year average increased precision and statistical significance of the estimates as well as changing the pattern of causation.

\section{Methodology}

This study utilizes annual time series data spanning the period 1980 to 2008 . A bivariate approach to investigate the relationship between domestic savings and economic growth is used. Using the savings growth literature as a basis and following from Tang and Chua, 2011; Mohan, 2006, the variables considered are real gross domestic product (GDP) as a proxy for economic growth measured in millions of Pula, domestic savings measured as the ratio between gross domestic savings (GDS) and GDP. The data is sourced from World Bank, World Development Indicators (WDI).

Model Specification: In empirical studies examining the relationship between savings and economic growth, a common feature of the studies is the use of a bilateral causality approach (Mohan 2006) and in some cases multilateral causality approach (Odhiambo, 2009). Incorporating the bilateral approach we specify gross domestic product as a function of national savings. The model takes the following form:

$$
\operatorname{lnGDP}{ }_{\mathrm{t}}=\alpha_{0}+\alpha_{1} \operatorname{lnGDS}_{\mathrm{t}}+\varepsilon_{\mathrm{t}}
$$

Where GDP is gross domestic product, GDS is the savings-GDP ratio. Both variables are specified in natural $\log$ form.

Autoregressive Distributed Lag (ARDL): This study employs the ARDL bounds testing approach to cointegration developed by Pesaran and Shin (1999) and later extended by Pesaran et al. (2001). The ARDL bounds test approach to cointegration has gained significance in econometric analysis in recent years based on the advantages it provides over techniques such as the Johansen - Juselius (JJ) cointegration and the 
dynamic Ordinary least squares (DOLS) technique. Firstly compared to the Johansson approach to cointegration, ARDL removes the restrictions found in traditional cointegration estimation approaches. It allows the undertaking of cointegration analysis irrespective of the order of integration of the underlying regressors. i.e. whether the regressors are integrated of zero order [I(0)], order one [I(1)]. The use of ARDL bounds test is therefore deemed suitable where the stationarity of a variable is called into question. Secondly, as suggested by Houge and Yosup (2009), since the issue of sample size is removed in the ARDL approach, this makes it appropriate for analyzing cointegration in small samples. Thirdly, when the model includes regressors that are endogenous, the bounds test approach provides unbiased long run estimates and valid $t$ statistics (Odhiambo, 2008). Lastly where the variables are cointegrated, the single equation ARDL estimator gives highly consistent estimates of the long-run parameters and valid $t$-ratios, even in the presence of endogenous explanatory variables (Inder, 1993). In addition, the JJ cointegration method is more efficient in multivariate systems, and the DOLS approach requires that the series in the model be non stationary.

Equation $\{1\}$ is therefore modeled as a conditional autoregressive distributed lag (ARDL) in a generic form as follows:

$\Delta G D P_{t}=\phi_{0}+\sum_{i=1}^{m} \Phi_{1 i} \Delta G D P_{t-i}+\sum_{j=0}^{n} \Phi_{2 j} \Delta G D S_{t-j}+\psi_{1} G D P_{t-1}+\psi_{2} G D S_{t-1}+\varepsilon_{t}$

Here $\Delta$ denotes first difference, $\mathrm{t}-1$ denotes one-period lag, $\sum_{i=1}^{m}$ denotes the sum from $\mathrm{i}=1,2,3, \ldots \mathrm{m} ; \sum_{j=0}^{n}$

denotes the sum of $\mathrm{j}=0,1,2, \ldots \mathrm{n}$; the parameters $\Phi_{\mathrm{i}}$ capture the coefficients of the short run dynamic, and $\psi_{\mathrm{k}}$ gives the long run estimates. The other variables are as defined above.

The cointegration equation is specified as:

$$
\hat{\psi}_{1} G D P_{t-1}+\hat{\psi}_{2} G D S_{t-1}=0
$$

The ARDL methodology requires examining the null hypothesis of a conditional or 'no conditional' relationship using the F-test which tests the joint significance of the lagged levels of the variables $\operatorname{InGDP}_{\mathrm{t}-1}$, $\operatorname{lnGDS}_{\mathrm{t}-1}$. The null and the alternative hypotheses of the long run relationship are:

$H_{0}: \psi_{1}=\psi_{2}=0$

$H_{1}: \psi_{1} \neq \psi_{2} \neq 0$

Critical values based on large samples between 500 and 40000 observations are developed by Pesaran et al. (2001), however, Narayan (2005) computes small sample critical values of 30-80 observations, and this is applicable to the present study. By way of interpretation if at a chosen significant level, the computed Fstatistic obtained from the F-test lies between the upper bound and the lower bound, there is no conclusive inference; if it exceeds the upper bound, we can reject the null hypothesis of no cointegration; but we cannot reject the null hypothesis if it lies below the lower bound. The short-run effects are captured by the coefficients of the variables in their first differences as shown in Eq. 2, while the long-run coefficients are obtained by first multiplying the coefficients of the one-period lag of the explanatory variable by a negative sign, then divide by the coefficient of the one-period lag of the dependent variable. That is, the long-run coefficient of the GDS is $-\left(\frac{\psi_{2}}{\psi_{1}}\right)$.

\section{Results and Discussion}

Unit root tests: The first step is to determine the stationarity characteristics of the variables. This can be done using tests such as the augmented Dickey-Fuller (ADF) and Phillip Perron (PP). The basic premise of the tests is that if the variables are integrated of order zero, then they are said to be stationary. Using Phillip Perron (PP) and Augmented Dickey Fuller (ADF) tests, the results indicate that GDP is stationary at levels and GDS is integrated of the first order. 
Table 1: Summary of Unit Root Results

\begin{tabular}{llllc}
\hline Variables & \multicolumn{2}{c}{ Levels } & \multicolumn{2}{c}{ Phillips-Perron } \\
& Intercept & Trend \& Intercept & Intercept & Trend \& Intercept \\
\hline GDP & -4.25 & -0.77 & - & - \\
DGS & -1.53 & -1.41 & $-4.56^{* * *}$ & $-8.72^{* * *}$
\end{tabular}

ADF

Variables

Levels

First difference

Intercept $\quad$ Trend \& Intercept $\quad$ Intercept $\quad$ Trend \& Intercept

$\begin{array}{lllll}\text { GDP } & -2.95 & -1.48 & - & -3.83^{* * *}\end{array}$

GDS $\quad-1.62 \quad-2.25$

Indicates significance at the ${ }^{* * *} 1 \%,{ }^{* *} 5 \%, * 1 \%$

A general model of ARDL is first performed with the lag length of three for the differenced variables. The decision on how many lags are appropriate is informed by the lag order selection criteria. Table 2 below indicates an appropriate lag length of three as selected by majority of the criterion.

Table 2: VAR Lag Order Selection Criteria

\begin{tabular}{lllllll}
\hline lag & LogL & LR & FPE & AIC & SC & HQ \\
\hline 0 & -18.05436 & NA & 0.012502 & 1.293830 & 1.386345 & 1.323987 \\
1 & 95.51691 & 205.1610 & $1.07 \mathrm{e}-05$ & -5.775284 & -5.497738 & -5.684811 \\
2 & 102.4254 & 11.58839 & $8.87 \mathrm{e}-06$ & -5.962927 & $-5.500351^{*}$ & -5.812139 \\
3 & 108.7635 & $9.813907^{*}$ & $7.70 \mathrm{e}-06^{*}$ & $-6.113775^{*}$ & -5.466168 & $-5.902672^{*}$ \\
\hline
\end{tabular}

* indicates lag order selected by the criterion. LR: sequential modified LR test statistic (each test at 5\% level). FPE: Final prediction error. AIC: Akaike information criterion. SC: Schwarz information criterion. HQ: Hannan-Quinn information criterion

Next the insignificant variables were gradually dropped, while observing the Akaike information criterion to ascertain the importance of the variables being dropped. The results are provided in table 3 below.

\section{Empirical Results}

Table 3: Estimated ARDL model based on equation 1

\begin{tabular}{lll}
\hline Variables & Coefficients & Std-Error \\
\hline D(LGDP(-1)) & $0.6784^{* * *}$ & 0.1695 \\
D(LGDP(-2)) & $-0.4176^{* *}$ & 0.1634 \\
D(LGDS) & $0.0969^{* *}$ & 0.0370 \\
D(LGDS(-1)) & $-0.0740^{* *}$ & 0.0366 \\
LGDP(-1)) & $-0.0538^{* * *}$ & 0.0167 \\
LGDS(-1) & $0.0780^{* *}$ & 0.0325 \\
C & $0.9589^{* * *}$ & 0.2775 \\
& & \\
Adjusted R-squared & 0.7018 & \\
SE of regression & 0.0211 & \\
F-statistic & 12.769 & \\
Prob(F-statistic) & 0.0000 &
\end{tabular}




\begin{tabular}{lll}
\hline Diagnostic Tests & & \\
Jarque-Bera & JB: & $0.431(0.806)$ \\
Serial Correlation LM Test + & F-statistic: & $0.225(0.799$ \\
Heteroskedasticity Test ++ & F-statistic: & $0.382(0.883)$ \\
Ramsey RESET Test & F-statistic: & $0.548(0.655)$
\end{tabular}

$10 \% ;{ }^{* *} \%$; ${ }^{* * *} 1 \%$. ${ }^{+B r e u s c h-G o d f r e y . ~}{ }^{++}$Breusch-Pagan-Godfrey

In order to establish the validity of the estimates, a number of diagnostic tests including the Jarque-Bera normality test, the Breusch-Godfrey serial correlation LM test, the Ramsey reset for model specification and ARCH test for heteroskedasticity are carried out. From the results of the diagnostic tests, the estimated residual of equation 2 is shown to be normal given the Jacque-Bera statistic 0.431 with a probability value of (0.806). Breusch-Godfrey serial correlation LM test statistic indicates that the estimates are free from serial correlation. The homoscedastic nature of the residuals is confirmed by the arch test statistic of 0.382 with a probability value of (0.883). Ramsey Reset test ascertains whether the correct functional form of the equation is used. The test statistic of 0.548 and the probability of (0.655) suggest that the correct functional forms have been used. To determine the stability of the parameters of the estimated equation, the CUSUM and CUSUM of squares test is carried out.

Figure 3: CUSUM and CUSUM of squares for equation 1
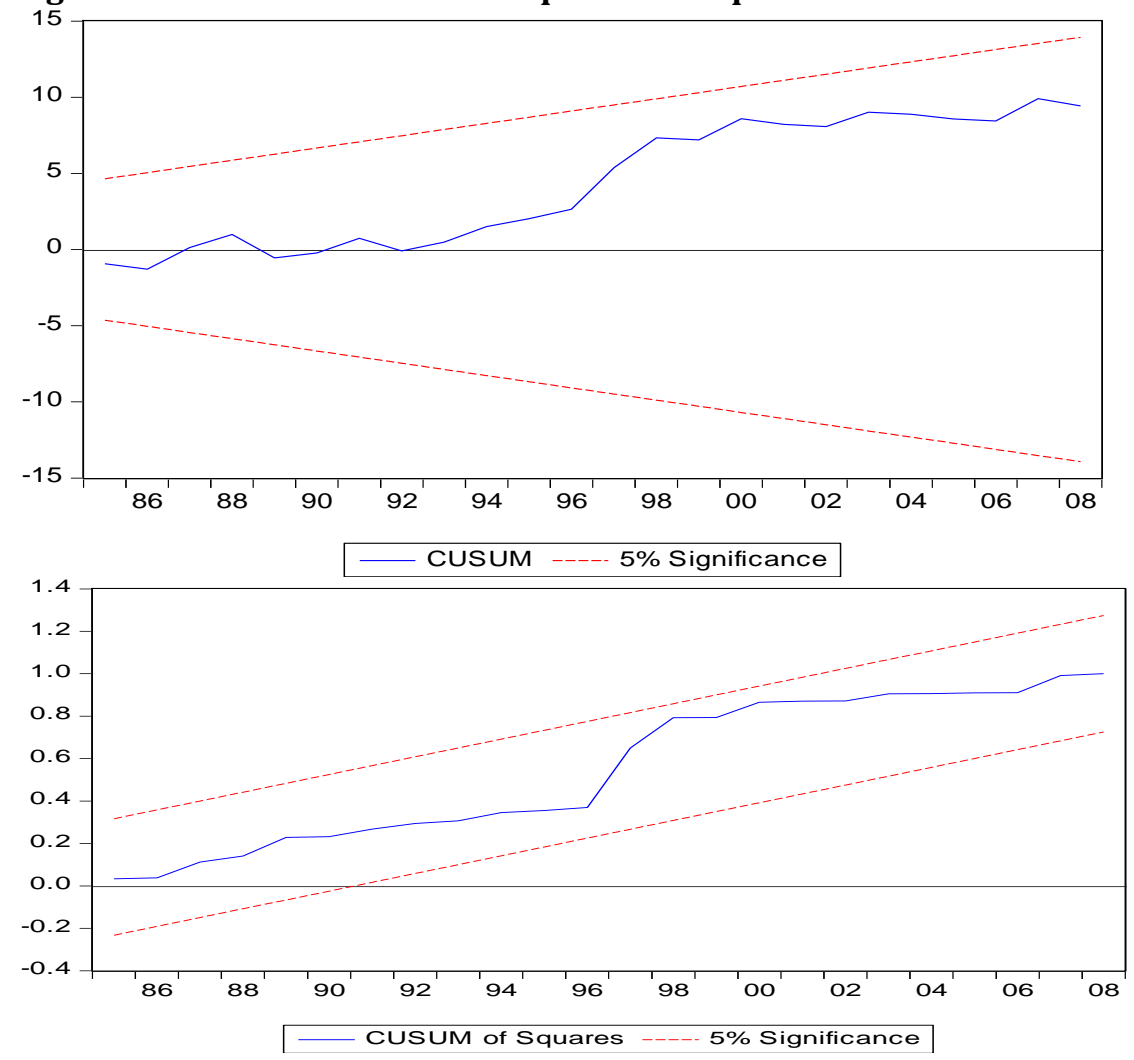

In these tests, the null hypothesis examines the stability of parameters at a significance level of $5 \%$. The confidence interval in these two tests is two straight lines that show a confidence interval of $95 \%$. If the test statistics is between these two lines, it is not possible to reject the null hypothesis showing the stability of the coefficients (Zare and Haghihgat, 2013). The result of CUSUM and CUSUM of squares test in figure 3 above point to the stability of the parameters. Overall, the Results indicate the soundness of the equations; correct specification of the model and the absence of serial correlation or heteroskedasticity. The next step is to 
ascertain the presence of a long run relationship amongst the variables. To do this we employ the bounds test, the results of which are presented in the table 4 below.

Table 4: Bounds test for Cointegration on ARDL equation 1

\begin{tabular}{|c|c|c|c|c|c|c|}
\hline \multicolumn{7}{|c|}{ Critical value bounds of the F statistics: unrestricted intercept and no trend (Critical Values) } \\
\hline \multirow{3}{*}{$\begin{array}{l}\text { F-statistics } \\
(\mathrm{k}=1, \mathrm{~T}=34)\end{array}$} & \multicolumn{2}{|c|}{$1 \%$ level } & \multicolumn{2}{|c|}{$5 \%$ level } & \multicolumn{2}{|c|}{$10 \%$ level } \\
\hline & $\mathrm{I}(0)$ & $\mathrm{I}(1)$ & $\mathrm{I}(0)$ & $\mathrm{I}(1)$ & $\mathrm{I}(0)$ & $\mathrm{I}(1)$ \\
\hline & 7.870 & 8.960 & 5.290 & 6.175 & 4.225 & 5.050 \\
\hline
\end{tabular}

Critical values obtained from Narayan (2005), Case III, p.1987. I(0) - lower bound; I(1) - upper bound. *10\%; **5\%; ${ }^{* * *} 1 \%$.

The result shows that the null of no cointegration between the variables is rejected in the case where GDP is taken to be the dependent variable. However, when LGDS is taken as the dependent variable, the null hypothesis of no cointegration cannot be rejected. The critical values obtained from Narayan (2005) show that the calculated F-statistic exceeds the upper critical limit at $10 \%$ and $5 \%$ levels. This therefore implies that there is a long-run relationship between these variables when GDP is the dependent variable.

Table 5: Short-run and long-run relationships

\begin{tabular}{lll}
\hline PANEL A & & \\
\hline Variables & Short Run & Long Run \\
GDS & $0.023^{* *}$ & $1.45^{* *}$ \\
\hline
\end{tabular}

*Significant at $5 \%$ level

The long run elasticities are calculated using the estimated coefficients of the level one period lag of the independent variable LGDS (-1) divided by the coefficient of the one level lag of the dependent variable, LGDP $(-1)$ and then multiplied by a negative sign. The short run elasticities are represented by the coefficients of the first differenced variables. In cases where there is more than one coefficient of an independent variable, these are then added up and their joint significance is tested using the Wald coefficient test. The short and long run estimated coefficients are provided in table 5 above. The regression results obtained in table four above indicate that there is a positive relationship between savings and economic growth in Botswana in both the short run and long run, with the impact of savings on GDP observed to be stronger in the long run than in the short run. Specifically, a one percent change in savings-GDP ratio in the long run yields a 1.45 percent increase in growth while in the short run, a one percent change in the savings-GDP ratio results in a 0.023 percent increase in growth.

\section{Conclusion and Policy Recommendations}

This study investigates the relationship between savings and economic growth in Botswana between 1980 and 2008. The study employed the bounds testing approach to cointegration in the examination of the savings-growth relationship in the economy. To test for the order of integration of the variables or the series, we employed both the Phillip Peron and the ADF tests. While the GDP series is found to be stationary at level, the savings series becomes stationary after being differenced once. Employing Bounds testing to cointegration, the results indicate that there is cointegration between economic growth and domestic savings when economic growth is taken to be the dependent variable. The main findings of the study is that domestic savings is an important aspect of growth in Botswana. In both the short and long run, domestic savings is positively and significantly related to growth. Specifically, this positive relationship is strongest in the long run. We therefore conclude that the savings - growth relationship in Botswana follows the growth theories of Solow (1956), McKinnon(1973) and Shaw (1973) of savings being essential for investment and economic growth. The role played by domestic savings and hence investment becomes crucial in supporting the country's diversified growth process. In light of the findings mentioned above, we make the following recommendations; 
- Measures to increase growth and economic diversification in Botswana should aim to create conducive financial environment that promotes domestic savings and increases domestic savings overall.

- Continued development of the financial sector ensuring access to financial instruments is essential.

- Fiscal and Monetary policies that allow for increased savings and that enhances domestic savings is vital.

\section{References}

Aghion, P., Comin, D., Howitt, P. \& Tecu, I. (2009). When Does Domestic Saving Matter for Growth? National Bureau of Economic Research. Working Paper 12275.

Anoruo, E. \& Ahmad, Y. (2001). Causal Relationship between Domestic Savings and Economic Growth: Evidence from Seven African Countries. African Development Bank, 13(2), 238-249.

Attanasio, O. P., Picci, L. \& Scorcu, A. E. (2000). Saving, Growth, and Investment: A Macroeconomic Analysis Using a Panel of Countries. The Review of Economics and Statistics, 82 (2), 182-211.

Bank of Botswana Annual Reports (Various Years).

Bacha, E. L. (1990). A Three-Gap Model of Foreign Transfers and the GDP Growth Rate in Developing Countries. Journal of Development Economics, 32, 279-96.

Carroll, C. D. \& Summers, L. H. (1991). Consumption Growth Parallels Income Growth: Some New Evidence in National Saving and Economic Performance, B. Douglas Bernheim and John B. Shoven, (Eds) University of Chicago Press, Chicago, 305-343.

Carroll, C. D. \& Weil, D. N. (1994). Saving and Growth: A Reinterpretation. Carnegie-Rochester Series on Public Policy, 40, 133- 192.

DeGregorio, J. (1992). Economic Growth in Latin America. Journal of Development Economics, 3, 59-84.

Dickey, D. A. \& Fuller, W. A. (1981). Likelihood Ratio Statistics for Autoregressive Time Series. Econometrica, 49, 1057-72.

Domer, E. (1946). Capital Expansion, Rate of Profit and Employment. Econometrica, 14(2), 137-147.

Edwards, S. (1996). Why are Latin America's savings rates so low? An International Comparative Analysis. Journal of Development Economics, 51, 5- 44.

Fry, M. J. (1995). Money and Banking in Economic Development. 2nd Ed. The Johns Hopkins University Press, Baltimore.

Giovannini, A. (1985) Saving and the Real Interest Rate in LDCs. Journal of Development Economics, 18, 197 217.

Harrod, R. F. (1939). An Essay in Dynamic Theory. Economic Journal. XLIX, 14-33.

Hoque, M. M. \& Yusop, Z. (2009). Impacts of Trade Liberalization on Aggregate Import in Bangladesh: An ARDL Bounds Test Approach. Journal of Asian Economics, 21, 37-52.

Inder, B. (1993). Estimating Long-Run Relationships in Economics: A Comparison of Different Approaches. Journal of Econometrics, 57, 53-68.

Japelli, T. \& Pagano, M. (1994). Savings, Growth and Liquidity Constraints. Quarterly Journal of Economics, 109, 83-109.

Johansen, S. \& Juselius, K. (1991). Maximum Likelihood Estimation and Inference on Cointegration - With Application to the Demand for Money. Oxford Bulletin of Econometrics and Statistics, 52,169-210.

Keynes, J. M. (1936). The General Theory of Employment, Interest and Money, Macmillan Cambridge University Press, Cambridge.

Lahiri, A. (1989). Dynamics of Asian Savings: The Role of Growth and Age Structure. IMF Staff Papers, 36(1), 228-260.

Lean, H. H. \& Song, Y. (2009). The Domestic Savings and Economic Growth Relationship in China. Journal of Chinese economic and Foreign Trade Studies, 2, (1), 5-17.

McKinnon, R. I. (1973). Money and Capital in Economic Development, Washington, DC: Brookings Institution.

Mohan, R. (2006). Causal Relationship between Savings and Economic Growth in Countries with Different Income levels. Economics Bulletin, 5(3), 1-12.

Narayan, P. K. (2005). The Saving and Investment Nexus for China: Evidence from Cointegration test. Applied Economics, 37, 1979 - 1990.

Odhiambo, N. M. (2008). Financial Depth, Savings and Economic Growth in Kenya: A dynamic Causal linkage. Economic Modeling, 25, 704-713. 
Odhiambo, N. M. (2009). Savings and Economic Growth in South Africa: A Multivariate Causality Test. Journal of Policy Modeling, 31(5), 708-718.

Pesaran, M. \& Shin, Y. (1999). An Autoregressive Distributed Lag Modeling Approach to Cointegration Analysis. In Strom, S(Ed), Econometrics and Economic Theory in the 20 th Century: The Ragner Frisch Centennial Symposium. Cambridge University Press, Cambridge.

Pesaran, M. H., Shin, Y. \& Smith, R. J. (2001). Bound Testing Approaches to the Analysis of Level Relationships. Journal of Applied Econometrics, 16, 289-326.

Romm, A. T. (2003). The Relationship between Savings and Growth in South Africa: An Empirical Study. TIPS/DPRU Forum 2003.

Saltz, I. S. (1999). An Examination of the Causal Relationship between Savings and Growth in the Third World. Journal of Economics and Finance, 23(1), 90-98.

Shaw, E. S. (1973). Financial Deepening in Economic Development. New York: Oxford University Press.

Sheggu, D. (2009). Causal Relationship between Growth and Real Gross Domestic Savings: Evidence from Ethiopia.

Sinha, D. \& Sinha, T. (1998). Cart before the Horse? The Saving-Growth Nexus in Mexico. Economics Letters, $61,43-47$.

Solow, R. M. (1956). A Contribution to the Theory of Economic Growth. Quarterly Journal of Economics, 70, 65-94.

Tang, C. F. \& Chua, Y. (2011). The Savings Growth Nexus for the Malaysian Economy: A View through Rolling Samples. Applied Economics, 44(32), 4173-4185.

Tsikata, Y. (1998). Saving in South Africa: An Empirical Investigation. (Unpublished; Washington: World Bank).

World Bank, World Economic Indicators (WDI) 2012 online database.

World Economic Outlook Online Database (2012)

Zare, M. \& Haghighat, A. (2013). Financial Liberalization and Stability of Short Run and Long Run Money Demand in Iran. Journal of Economics and Behavioral Studies, 5(1), 24-37. 